\title{
COMMENT
}

\section{Thermotolerance and the 'Pompeii worms'}

\author{
Pierre Chevaldonné ${ }^{1, *}$, Charles R. Fisher ${ }^{2}$, James J. Childress ${ }^{3}$, Daniel Desbruyères ${ }^{4}$, \\ Didier Jollivet $^{5}$, Franck Zal ${ }^{5}$, André Toulmond ${ }^{5}$ \\ ${ }^{1}$ Centre d'Océanologie de Marseille, UMR CNRS 6540 DIMAR, Station Marine d'Endoume, Rue de la Batterie des Lions, \\ 13007 Marseille, France \\ ${ }^{2}$ Department of Biology, 208 Mueller Laboratory, The Pennsylvania State University, University Park, Pennsylvania 19802, USA \\ ${ }^{3}$ Marine Science Institute, University of California, Santa Barbara, California 93106, USA \\ ${ }^{4}$ IFREMER Centre de Brest, BP 70, 29280 Plouzané, France \\ ${ }^{5}$ Observatoire Océanologique de Roscoff, CNRS-UPMC, Station Biologique, BP 74, 29682 Roscoff Cedex, France
}

Deep-sea hydrothermal-vent organisms are often cited as examples of adaptation to extreme environmental conditions. Since the discovery of the first 'black smokers' (the vent chimneys expelling superheated metal-laden fluids), the polychaete worm Alvinella pompejana has been considered the invertebrate most exposed to the harsh conditions, hence its nickname 'Pompeii worm' (Desbruyères \& Laubier 1980). As a result, its ecology and biochemistry have received considerable attention. Several years ago, some of us (P.C., D.D. \& J.J.C.) observed a live A. pompejana seemingly unaffected by temperatures above $100^{\circ} \mathrm{C}$ (Chevaldonné et al. 1992). Cautiously, we did not propose that Pompeii worms can live and prosper at such temperatures, but that they can withstand brief exposures to extreme heat. More recently, Cary et al. (1998), using a clever new device, reported additional observations that only corroborate previous findings (Desbruyères et al. 1982, Chevaldonné et al. 1991, 1992, Chevaldonné 1996) but concluded that the worms have body temperatures well above $60^{\circ} \mathrm{C}$, with their 'proteins, chromosomes, nucleic acid processing machinery and other macromolecules' ...functioning... 'at temperatures above $80^{\circ} \mathrm{C}$ '. Considering the general significance of this conclusion, it is important to make clear that although some of the observations reported by Cary et al. have long been accepted by hydrothermal vent biologists, the spectacular conclusions proposed by these authors contradict a substantial body of biochemical evidence. We here review the facts and evidence overlooked by Cary et al., address methodology issues, and set our knowledge of the Pompeii worm's ecophysiology back into a more cautious and reasonable perspective.

*E-mail: chevaldonne@com.univ-mrs.fr
Thermal tolerance is usually defined through experimentally-measured parameters $\left(\mathrm{T}_{\mathrm{L} 50}, \mathrm{CTMax}\right.$, heat stupor point), which are regarded as characterising the physiological, ecological or behavioural tolerance limits. Another approach is to determine the actual body temperatures by inserting fine gauge thermocouples into live animals released into their natural environment. To date, with 1 exception (Mickel \& Childress 1982), most of the information on the thermal tolerance of vent species consists of attempts to characterise their microhabitat and in vitro biochemical studies. Because Pompeii worms inhabit environments with the steepest temperature gradients and potential exposure to the highest temperatures, there has been substantial interest in their capacities. Unfortunately these polychaetes have never been maintained alive on board ship for experiments, despite numerous attempts to do so. As a result the only direct data on their temperature tolerance come from studies of isolated tissues, organelles and biomolecules.

Table 1 summarises the information available to date on the thermal stability of Pompeii worm macromolecules and organelles. In addition, recent observations of unusually high numbers of linker chains (involved in maintaining the quaternary structure) in the extracellular hemoglobin of these worms concur to suggest an improved thermostability for this molecule, but most likely not above $50^{\circ} \mathrm{C}$ (Zal et al. 1997). Taken together these data suggest that Alvinella pompejana is indeed the most thermotolerant hydrothermal-vent metazoan investigated to date. Some of these indices, like enzyme thermal stabilities, are only roughly indicative of possible heat tolerance of the organism, and are most useful for comparative purposes. Some others such as the collagen denaturation temperatures, or the Arrhenius break temperatures for mitochondrial 
Table 1. Alvinella pompejana thermotolerance: biochemical data

\begin{tabular}{|lll|}
\hline Parameter measured & Max. temperature $\left({ }^{\circ} \mathrm{C}\right)$ & Source \\
\hline Mitochondrial respiration (Arrhenius break temperature) & 49 & Dahlhoff et al. (1991) \\
Hemoglobin optimal cooperativity & 30 & Toulmond et al. (1990) \\
Hemoglobin dissociation & 50 & Terwilliger \& Terwilliger (1984) \\
Kinetics of cytosolic malate dehydrogenases (cMDHs) & 31 & Dahlhoff \& Somero (1991) \\
Thermal stability of aspartate-amino transferase & 61 & Jollivet et al. (1995) \\
Thermal stability of glucose-6-phosphate isomerase & 52 & Jollivet et al. (1995) \\
rDNA denaturation & 87 & Dixon et al. (1992) \\
Cuticle collagen denaturation & 45 & Gaill et al. (1995) \\
Interstitial collagen denaturation & 46 & Gaill et al. (1995) \\
\hline
\end{tabular}

metabolism, have been extensively referenced to shallow living species and are accepted as good predictors of temperature tolerances (Dahlhoff et al. 1991, Gaill et al. 1995, Guderley \& St Pierre 1996). However the data summarised in Table 1 also suggest a maximum physiological body temperature below $50^{\circ} \mathrm{C}$, and that allowing the body temperature to rise to $50^{\circ} \mathrm{C}$ for an extended period of time would be lethal.

This conclusion seems to be in conflict with the substantially higher in situ habitat temperatures reported by Cary et al. (1998) and numerous other investigators over the years (Desbruyères et al. 1982, Chevaldonné et al. 1991, 1992, Chevaldonné 1996). However, none of these studies measured the body temperatures of Pompeii worms in situ. Reliable, long-term temperature records exist of the environment directly adjacent to the anterior end of the worms tubes, which all indicate a similar pattern: a strong temporal and spatial variability, with temperature ranging from $2^{\circ} \mathrm{C}$ to about $25^{\circ} \mathrm{C}$ (mean $=6$ to $12^{\circ} \mathrm{C}$ ), rarely $45^{\circ} \mathrm{C}$ (Chevaldonné et al. 1991, 1992, Chevaldonné 1996). Deeper within the tube, although temperature likely increases, the exact nature of the thermal environment remains a mystery. Tubes have tortuous shapes and they are not mechanically robust (they have been compared to parchment and are punctured by probes during attempts to monitor inside temperature). They are rarely straight over more than 2 to $3 \mathrm{~cm}$; thus, no matter how gently the probe is introduced into the tubes there is a very high probability that the tube will be punctured, the worm will be displaced or water flow patterns disrupted. Indeed, the diameter of the probe deployed by Cary et al. $(0.75 \mathrm{~cm})$ is only slightly smaller than the maximum recorded width $(1.2 \mathrm{~cm})$ of Alvinella pompejana (Jollivet 1993, Desbruyères et al. 1998). Cary et al. did not indicate the size of the monitored tubes, but it is safe to assume they tried to force an object about the size of a worm into a tube fit for only 1 individual. Also, tubes, in addition to the cuticle, offer an efficient thermal protection (Gaill \& Hunt 1986), and they do not 'channel the hot fluids over the worm's body', as proposed by Cary et al. (1998). The worms can only build their tubes when the chimney walls are sealed from the superheated fluids (Chevaldonné 1996, Desbruyères et al. 1998). Regardless of the diameter of the probe, it is impossible to unambiguously ascertain, without the help of a device such as an endoscopic camera, that the temperature sensor was 'adjacent to a worm's tail' (Cary et al. 1998), when the worm might have been disturbed by the device. 'Adjacent' is a very imprecise word in a temporally variable microhabitat where the spatial gradients of temperature are arguably the greatest of any habitat on the planet. Because of the gradient and the nature of the tubes, obtaining in situ temperature measurements indicative of the worms' body temperatures is virtually impossible. Even with very fine scale spatial and temporal control of the measurements one must assume that the cuticle and its thick covering of ectosymbiotic bacteria, coupled with the behaviour and currents created by the living animals (ventilation is common among tube-dwelling polychaetes), will dramatically affect the actual body temperature experienced by the worms (Chevaldonné et al. 1991).

In the same way, Cary et al. (1998) indicated that they could 'monitor unoccupied tubes', which is also impossible without an endoscope. Some individuals may indeed remain hidden inside their tubes for extended periods of time (Chevaldonné \& Jollivet 1993). Alvinella pompejana are extremely sedentary and rarely leave their dwelling tubes unless disturbed by submersible manipulations (Chevaldonné \& Jollivet 1993). In contrast, Cary et al. (1998) report that 'individuals make regular excursions of up to $1 \mathrm{~m}$ to feed', which undoubtedly indicates that (1) the submersible operations greatly disturbed the Pompeii worm population, or (2) authors have confused A. pompejana with the sympatric alvinellid Paralvinella grasslei, which does move a lot around its dwelling tube, and never entirely retracts into it (Chevaldonné \& Jollivet 1993).

Although Pompeii worms undoubtedly live in close association to one of the hottest environments on the 
planet colonised by metazoans, and perhaps survive brief external exposure to higher temperatures than other metazoans (Chevaldonné et al. 1992), their physiological thermotolerance appears to be only in the range of other high temperature adapted invertebrates. In addition to Cataglyphis desert ants (ca $50^{\circ} \mathrm{C}$; Wehner et al. 1992) referred to by Cary et al. (1998), the pseudoscorpion Eremogarypus perfectus, with a heat stupor point of $65^{\circ} \mathrm{C}$ (Heurtault \& Vannier 1990), is the most thermotolerant metazoan documented. Some fungi that can grow at temperatures up to $65^{\circ} \mathrm{C}$ (Brock 1978) are, however, the most thermophilic eukaryotes known. Water has a much higher heat capacity than air, and until a direct study on the thermotolerance of Alvinella pompejana provides new information, Potamocypris ostracods living at $55^{\circ} \mathrm{C}$ in hot springs in Oregon (Wickstrom \& Castenholz 1973) are the most thermotolerant aquatic animals we are aware of.

There is no evidence that Alvinella pompejana experience body temperatures even close to $80^{\circ} \mathrm{C}$, and (with the normal exception of rDNA, for which denaturation is typically 30 to $40^{\circ} \mathrm{C}$ above the tolerated temperature) no macromolecules that resist such temperatures have been reported (Table 1). Pompeii worms have an array of macromolecules clearly adapted to temperatures toward the upper limits of metazoan life, but survival in their habitat requires morphological and behavioural adaptations to avoid sustained, high body temperatures.

\section{LITERATURE CITED}

Brock TD (1978) Thermophilic microorganisms and life at high temperatures. Springer-Verlag, New York

Cary SC, Shank T, Stein J (1998) Worms bask in extreme temperatures. Nature 391:545-546

Chevaldonné P (1996) Ecologie des cheminées hydrothermales actives. Université de la Méditerranée, Marseille

Chevaldonné P, Jollivet D (1993) Videoscopic study of deepsea hydrothermal vent alvinellid polychaete populations: biomass estimation and behaviour. Mar Ecol Prog Ser 95: 251-262

Chevaldonné $P$, Desbruyères $D$, Le Haître M (1991) Timeseries of temperature from three deep-sea hydrothermal vent sites. Deep-Sea Res 38:1417-1430

Chevaldonné $\mathrm{P}$, Desbruyères $\mathrm{D}$, Childress JJ (1992) Some like it hot... and some even hotter. Nature 359:593-594

Dahlhoff E, Somero GN (1991) Pressure and temperature adaptation of cytosolic malate dehydrogenases of shallowand deep-living marine invertebrates: evidence for high body temperatures in hydrothermal vent animals. J Exp Biol 159:473-487

Dahlhoff E, O'Brien J, Somero GN, Vetter RD (1991) Temperature effects on mitochondria from hydrothermal vent invertebrates: evidence for adaptation to elevated and variable habitat temperatures. Physiol Zool 64:1490-1508
Desbruyères D, Laubier L (1980) Alvinella pompejana gen sp. nov., Ampharetidae aberrant des sources hydrothermales de la ride Est-Pacifique. Oceanol Acta 3:267-274

Desbruyères D, Crassous P, Grassle J, Khripounoff A, Reyss D, Rio M, Van Praet M (1982) Données écologiques sur un nouveau site d'hydrothermalisme actif de la ride du Pacifique oriental. C R Acad Sci Paris, Sér III 295:489-494

Desbruyères D, Chevaldonné $\mathrm{P}$, Alayse AM, Jollivet $\mathrm{D}$, Lallier FH, Jouin-Toulmond C, Zal F, Sarradin PM, Cosson R, Caprais JC, Arndt C, O'Brien J, Guezennec J, Hourdez S, Riso R, Gaill F, Laubier L, Toulmond A (1998) Biology and ecology of the 'Pompeii worm' (Alvinella pompejana Desbruyères and Laubier), a normal dweller of an extreme deep-sea environment: a synthesis of current knowledge and recent developments. Deep-Sea Res II 45:383-422

Dixon DR, Simpson-White R, Dixon LRJ (1992) Evidence for thermal stability of ribosomal DNA sequences in hydrothermal-vent organisms. J Mar Biol Assoc UK 72:519-527

Gaill F, Hunt S (1986) Tubes of deep sea hydrothermal vent worms Riftia pachyptila (Vestimentifera) and Alvinella pompejana (Annelida). Mar Ecol Prog Ser 34:267-274

Gaill F, Mann K, Wiedemann H, Engel J, Timpl R (1995) Structural comparison of cuticle and interstitial collagens from annelids living in shallow sea-water and at deep-sea hydrothermal vents. J Mol Biol 246:284-294

Guderley HE, St Pierre J (1996) Phenotypic plasticity and evolutionary adaptations of mitochondria to temperature. In: Johnston IA, Bennett AF (eds) Animals and temperature: phenotypic plasticity and evolutionary adaptation. Cambridge University Press, Cambridge, p 127-152

Heurtault J, Vannier G (1990) Thermorésistance chez deux pseudoscorpions (Garypidae), l'un du désert de Namibie, l'autre de la région de Gênes (Italie). Acta Zool Fenn 190: 165-171

Jollivet D (1993) Distribution et evolution de la faune associée aux sources hydrothermales profondes à $13^{\circ} \mathrm{N}$ sur la dorsale du Pacifique oriental: le cas particulier des polychètes Alvinellidae. Université de Bretagne Occidentale, Brest

Jollivet D, Desbruyères D, Ladrat C, Laubier L (1995) Evidence for differences in the allozyme thermostability of deep-sea hydrothermal vent polychaetes (Alvinellidae): a possible selection by habitat. Mar Ecol Prog Ser 123: 125-136

Mickel TJ, Childress JJ (1982) Effects of pressure and temperature on the EKG and heart rate of the hydrothermal vent crab Bythograea thermydron (Brachyura). Biol Bull 162:70-82

Terwilliger NB, Terwilliger RC (1984) Hemoglobin from the 'Pompeii worm', Alvinella pompejana, an annelid from a deep sea hot hydrothermal vent environment. Mar Biol Lett 5:191-201

Toulmond A, El Idrissi Slitine F, De Frescheville J, Jouin C (1990) Extracellular hemoglobins of hydrothermal vent annelids: structural and functional characteristics in three alvinellid species. Biol Bull 179:366-373

Wehner R, Marsh AC, Wehner S (1992) Desert ants on a thermal tightrope. Nature 357:586-587

Wickstrom CE, Castenholz RW (1973) Thermophilic ostracod: aquatic metazoan with the highest known temperature tolerance. Science 181:1063-1064

Zal F, Green BN, Lallier FH, Toulmond A (1997) Investigation by electrospray ionization mass spectrometry of the extracellular hemoglobin from the polychaete annelid Alvinella pompejana: an unusual hexagonal bilayer hemoglobin. Biochemistry 36:11777-11786 